\title{
Inter-hospital transport of critically ill patients: the reality of a hospital in the Northeast region of Portugal
}

Transporte inter-hospitalar do doente crítico: a realidade de um hospital do nordeste de Portugal

Transporte interhospitalario del paciente en situación crítica: la realidad de un hospital del nordeste de Portugal

Andreia Catarina Gonçalves da Graça*; Norberto Anibal Pires da Silva**; Teresa Isaltina Gomes Correia***;

Matilde Delmina da Silva Martins ${ }^{* * * *}$

\begin{abstract}
Background: The need to transfer patients between health institutions is an unquestionably current subject.

Objective: To characterize the supervision of patients during inter-hospital transport.

Methodology: Retrospective cross-sectional study. The study included 184 patients from an emergency department in the northeast region of Portugal who were transferred between hospitals under the supervision of the services team between November 2015 and October 2016.

Results: Among the transferred patients, 58.7\% were men; 33.2\% were aged $71-80$ years; the most common diagnosis was neurological disease $(31.5 \%) ; 15.8 \%$ of them had a risk score $0-2 ; 45.7 \%$ a risk score $3-6 ; 18.5 \%$ had a risk score $\geq 7$; and $20.1 \%$ had a risk score $<7$ and item scoring 2 points. They were supervised by a nurse $(77.2 \%)$ or by a physician and a nurse $(22.8 \%)$.

Conclusion: The risk score influences the type of supervision during inter-hospital transport. Most patients with a higher risk score were supervised by a physician and a nurse.
\end{abstract}

Keywords: transportation of patients; critical care; patient care

\section{Resumo}

Enquadramento: A necessidade de transferir doentes entre instituiçôes de saúde é um assunto incontestavelmente atual.

Objetivo: Caracterizar o tipo de acompanhamento dos doentes sujeitos a transporte inter-hospitalar.

Metodologia: Estudo transversal retrospetivo. Estudaram-se 184 doentes, oriundos de um serviço de urgência do nordeste de Portugal, sujeitos a transporte inter-hospitalar com acompanhamento da equipa própria do serviço, entre novembro de 2015 e outubro de 2016.

Resultados: Do total dos doentes transferidos, 58,7\% era do género masculino, $33,2 \%$ com idades entre os 71-80 anos e o diagnóstico mais frequente foi a doença neurológica $(31,5 \%)$. Verificou-se que $15,8 \%$ dos doentes apresentaram score de risco entre $0-2,45,7 \%$ apresentaram score entre 3-6 pontos, $18,5 \%$ tiveram score $\geq$ 7 pontos e $20,1 \%$ tiveram score $<7$ pontos e item com pontuação 2. Foram acompanhados por enfermeiro $77,2 \%$ e médico e enfermeiro $22,8 \%$.

Conclusáo: $\mathrm{O}$ score de risco influencia o tipo de acompanhamento no transporte inter-hospitalar. Os doentes com score de risco mais elevado foram acompanhados maioritariamente por médico e enfermeiro.

Palavras-chave: transporte de pacientes; cuidados críticos; assistência ao paciente

*RN, Local Health Unit, Northeast, EPE - Hospital Unit of Bragança, 5301-852, Bragança, Po tugal [graca.andreia@gmail.com]. Contribution to the article: literature search; data colletion, statistical treatment and evaluation, article writing; data analysis, discussion and artic writing. Address for correspondence: Avenida Abade de Baçal, 5301-852, Bragança, Portugal. 5301-852, Braganca, Portugal [norbertosiva @ sapo.pt). Contribution to the article: literature search; data collection, statistical treatment and evaluation, article writing; data analysis, discussion and article writing.

***Ph.D., Coordinating Professor, School of Health, Polytechnic Institute of Bragança 5300-146, Bragança, Portugal [teresaicorreia@ipb.pt]. Contribution to the article: literature search; data collection, statistical treatment and evaluation, article writing; data analysis, discussion and article writing.

*****Ph.D., Adjunct Professor, School of Health, Polytechnic Institute of Bragança, 5300-146, Braganca, Portugal [matildemartins@ipb.pt]. Contribution to the article: literature search and article writing.

\section{Resumen}

Marco contextual: La necesidad de transferir pacientes entre instituciones sanitarias es un asunto indiscutiblemente actual.

Objetivo: Caracterizar el tipo de seguimiento de los pacientes sujetos al transporte interhospitalario.

Metodología: Estudio transversal retrospectivo. Se estudiaron 184 pacientes, provenientes de un servicio de urgencias del nordeste de Portugal, sujetos al transporte interhospitalario acompańados por el equipo del servicio, entre noviembre de 2015 y octubre de 2016.

Resultados: Del total de los pacientes transferidos, el $58,7 \%$ era del género masculino, el $33,2 \%$ con edades comprendidas entre los 71 y 80 años, y el diagnóstico más frecuente fue enfermedad neurológica, 31,5\%. Se observó que el 15,8\% de los pacientes presentó una puntuación de riesgo entre 0 y 2, el 45,7\% presentó una puntuación entre 3 y 6 , el 18,5\% tuvo una puntuación de $\geq 7$ puntos y el $20,1 \%$ una puntuación de $<7$ puntos y un ítem con puntuación 2 . Al 77,2\% les acompañó un enfermero, y al 22,8\% un médico y un enfermero.

Conclusión: La puntuación de riesgo influye en el tipo de acompañamiento en el transporte interhospitalario. A los pacientes con una puntuación de riesgo más elevada les acompañaron mayoritariamente un médico y un enfermero.

Palabras clave: transporte de pacientes; cuidados críticos; atención al paciente

Received for publication: 24.05 .17

Accepted for publication: 23.10.17

Série IV - n. ${ }^{\circ} 15$ - OUT./NOV./DEZ. 2017 


\section{Introduction}

The recent changes in the structure of the Portuguese National Health Service (Serviço Nacional de Saúde, SNS) and the reorganization of some hospital treatment and diagnosis services have contributed to the need for transferring patients between different institutions in pursuit of the best approach to different situations. The decision to transport critically ill patients should always take into account the benefit-risk assessment since the transport of patients increases the risk of morbidity and mortality. For the first time in 1992, the American Society of Critical Care Medicine published guidelines for inter-hospital transport. In 1997, the Portuguese Society of Intensive Care (Sociedade Portuguesa de Cuidados Intensivos, SPCI) developed a guide on patient transfer that emphasized the need for correct transport planning in order to minimize risks. In 2001, the Working Group in Emergencies of the North Regional Health Administration (Administração Regional de Sauide do Norte, ARSN) published the regulation for secondary transfer. This document was later updated in 2006. In 2008, the SPCI and the Portuguese Medical Association (Ordem dos Médicos, OM) elaborated a document with recommendations for the transfer of critically ill patients with the purpose of minimizing potential risks and making it more efficient. This document complemented the already existing documentation on the topic. The inter-hospital transport of patients should be investigated in order to obtain valid information and implement corrective actions, if necessary, as well as to contribute to the development of other studies. The professionals who supervise the patient during transport are responsible for making decisions to anticipate and resolve any potential incident during transfer, thus contributing to a successful transport.

The general objective of this study was to characterize the supervision of patients during inter-hospital transport. Its specific objectives were: to determine if the type of patient supervision depends on the transport risk score; to determine if the type of patient supervision is influenced by the reason for transfer; to associate the clinical diagnosis with the type of patient supervision; and to analyze if the type of patient supervision is influenced by the medical specialty unit from which the patient is being transferred.

\section{Background}

The emergency department has become patients' entry point into the SNS for several reasons, which requires an organized and hierarchical referral network. Referral networks aim to regulate institutional complementarity with the purpose of ensuring that all patients have access to all services of the SNS (Comissão de Reavaliação da Rede Nacional de Emergência/ Urgência, 2012).

In Portugal, services in the emergency network are classified in ascending order, according to resource availability and response capacity (Despacho no 10319/2014 de 11 de agosto): basic emergency service (serviço de urgência básica, SUB), medical-surgical emergency service (serviço de urgência medico-cirúrgica, SUMC), and polyvalent emergency service (serviço de urgência polivalente, SUP).

In addition to responding to urgency and emergency situations in their area of influence, these services complement each other in order to achieve a differentiated network.

\section{Critically ill patients}

The SPCI and the OM define a critically ill patient "as a patient whose survival, due to severe dysfunction or failure of one or more organs or systems, depends on advanced means of monitoring and therapy" (Ordem dos Médicos [Comissão da Competência em Emergência Médica] e Sociedade Portuguesa de Cuidados Intensivos, 2008, p. 8).

Patients' current or impending multiple organ failure syndrome means that they have virtually no physiologic reserve or ability to adapt to sudden changes. Thus, the smallest change can make them vulnerable to great instability and clinical deterioration. Changes have a multiplier effect in the worsening of patients' clinical condition.

Therefore, inter-hospital transport is recommended in two situations: in case of lack of human or technical resources to treat and diagnose the patient, and in case of bed unavailability at the hospital of origin (Ordem dos Médicos [Comissão da Competência em Emergência 
Médica] e Sociedade Portuguesa de Cuidados Intensivos, 2008).

According to the SPCI and the OM, inter-hospital transport involves risks. Therefore, it is essential to perform a benefit-risk assessment of the impact that the transfer may have on the patient's treatment, diagnosis, and final outcome. The less differentiated is an emergency department, the higher will be the likelihood of an inter-hospital transport. The National Institute of Medical Emergency (Instituto Nacional de Emergência Médica, INEM, 2012) describes patient transport as a period of great instability for patients, which can aggravate their clinical condition and lead to complications that must be anticipated. This document corroborates the recommendations of Ordem dos Médicos [Comissão da Competência em Emergência Médica] e Sociedade Portuguesa de Cuidados Intensivos (2008) by stating that the professionals who decide, plan, assist, and transport patients are responsible for identifying, understanding, and minimizing the risks involved in the transfer, as well as for making decisions aimed at improving the patient's prognosis. Furthermore, the level of supervision, surveillance, and care during transport should at least correspond to the level found in the unit of origin. The inadequate preparation - of the patient and/or the transport team - can lead to a suboptimal care delivery.

\section{Inter-hospital transport}

Inter-hospital patient transport consists in the transfer of patients between hospitals (Lacerda, Cruvinel, \& Silva, 2011). Nowadays, since not every hospital has every option available, there is an increasing need to transfer patients to a hospital where they can receive adequate care based on their clinical situation.

According to the same authors, and in line with the INEM (2012), patient transport involves the following phases: Decision - it is a medical act, it assumes that benefits and risks have been assessed. Transport risk has two components: the clinical risk, which depends on the factors that affect the cardiorespiratory physiology and the reliability of monitoring - effects of vibrations and possible temperature changes - and the travel risk (acceleration, deceleration, and risk of collision, which increase significantly with speed); Planning - it is carried out by the medical and nursing teams. Proper planning can help avoiding most patient transport incidents. It requires good coordination within the team that transfers the patient, communication between the units that refer and receive the patient, the stabilization of the patient, the selection of a team, the use of proper equipment and means of transport, and adequate patient documentation; Implementation - the selected team is responsible for the patient's transport up until the arrival at the unit of destination or, in the case of transport for complementary exams or therapeutic interventions, until the patient's return to the hospital of origin. It has equal responsibilities to those of the team who transports the patient. The level of care during transport should not be lower than the care provided at the unit of origin. Rua (1999) argues that, despite the difficulties inherent to inter-hospital transport, it can be performed safely when it is planned and carried out by an experienced team and using appropriate equipment. According to the Ordem dos Médicos (Comissão da Competência em Emergência Médica) e Sociedade Portuguesa de Cuidados Intensivos (2008), argue that the team's technical qualifications (i.e., level of training and clinical experience) is one of the most important aspects for patient safety during transport. However, the authors emphasize that experience in hospital settings is not enough. Even professionals experienced in caring for critically ill patients need specific training on care delivery to critically ill patients during the transport. The transport of patients poses risks that must be considered at the time of the decision. $\mathrm{Pa}$ tients should only be transferred when their clinical condition is not directly or indirectly worsened as a result of the transport. The adequate preparation of both the patient and the transport team is essential to an optimal care delivery between the units of origin and destination (INEM, 2012).

\section{Transport risk score}

According to the recommendations of the Ordem dos Médicos (Comissão da Competência em Emergência Médica) e Sociedade Portuguesa de Cuidados Intensivos (2008), the identification of the necessary level of care during transport involves the completion of an assessment grid to determine the risk score (Figure 1). 


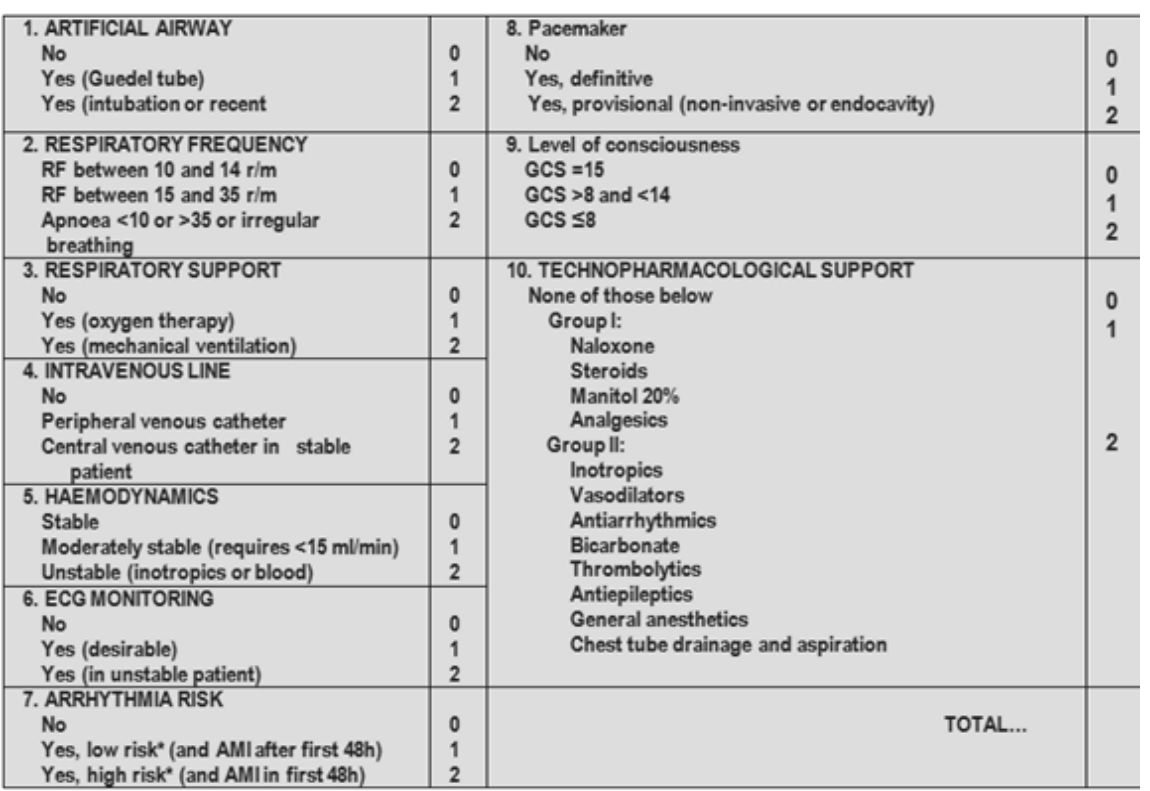

${ }^{*}$ Low risk $=$ without immediate life risk or need for immediate therapeutic intervention.

${ }^{*}$ High risk $=$ immediate life risk or need for immediate therapeutic intervention.

\begin{tabular}{|c|c|c|c|c|c|}
\hline POINTS & LEVEL & VEHICLE & TEAM & MONITORING & EQUIPMENT \\
\hline 0.2 (only O2 and IV) & A & $\begin{array}{c}\text { Conventional } \\
\text { ambulance }\end{array}$ & $\begin{array}{c}\text { Emergency medical } \\
\text { responder }\end{array}$ & None & Standard first-aid equipment \\
\hline $\begin{array}{c}3-6 \text { (no items scoring } \\
\text { 2) }\end{array}$ & B & $\begin{array}{c}\text { Conventional } \\
\text { ambulance }\end{array}$ & Nurse & $\begin{array}{c}\text { SaO2, ECG, HR, } \\
\text { noninvasive BP }\end{array}$ & $\begin{array}{c}\text { Above mentioned + } \\
\text { transport monitor, injectable } \\
\text { solutions + saline }\end{array}$ \\
\hline $\begin{array}{c}\text { scoring 2) } \\
\text { or if item }\end{array}$ & C & $\begin{array}{c}\text { Physician-staffed } \\
\text { ambulance or air } \\
\text { ambulance }\end{array}$ & Physician + Nurse & $\begin{array}{c}\text { SaO2, ECG, HR, } \\
\text { BP, and } \\
\text { eapnography if } \\
\text { necessary }\end{array}$ & $\begin{array}{c}\text { Above mentioned + } \\
\text { transport ventilator + } \\
\text { advanced airway devices, } \\
\text { defibrillator with pacemaker, } \\
\text { syringes, and infusion } \\
\text { pumps }\end{array}$ \\
\hline
\end{tabular}

Figure 1. Patient Transport Risk Stratification Scale (Escala de Estratificação de Risco em Transporte de Doentes).

Ordem dos Médicos (Comissão da Competência em Emergência Médica) e Sociedade Portuguesa de Cuidados Intensivos (2008).

This transport risk score was designed by Etxebarría et al. (1998) to identify the necessary human resources, equipment, and vehicle to supervise and monitor patients according to the severity of their condition. International studies (Etxebarría et al., 1998; Kulshrestha \& Singh, 2016) have documented the risk inherent to patient transport. Sethi and Subramanian (2014) have concluded that patients with a risk score $\geq 7$ are at high risk for critical events and subsequent mortality. In this case, continuity of care should be maintained during the inter-hospital transport, and the team must be trained and qualified to anticipate, manage, and resolve any technical and medical difficulties that may arise during transport. Kulshrestha and Singh (2016) reinforce this idea while also emphasizing that the decision to transport a patient based on the benefit-risk assessment and its planning based on team communication and risk score are essential to determine the risk of transport, both for the patient and the transport team. Droogh, Smit, Absalom, Ligtenberg, and Zijlstra (2015) argue that, despite the use of scores, the transport itself can also influence the severity score to the extent that inter-hospital transport is associated with the risk of physiological deterioration and adverse events. This risk is proportional to the patient's level of 
severity before the transport and the team's level of experience and knowledge. The authors also mention that a specialized team, that is adjusted to the transport risk score, will be better able to stabilize the patient before transfer and anticipate or respond to complications, which results in fewer and less severe adverse events. According to Nunes (2009), the transport must be carried out with the lowest possible risk and the highest possible safety to ensure the patient's right to quality care, of which safety is a critical component. The author also emphasizes that, in their decision-making process, nurses may refuse to accompany the patient if, after analyzing the factors involved, they conclude that the minimum and desirable conditions are not in place to transport the patient safely and with the least possible risk, both for the patient and the team.

\section{Research question}

What is the type of supervision of patients during inter-hospital transport?

\section{Methodology}

A retrospective cross-sectional study was conducted between November 2015 and October 2016 at the SUMC of the Northeast Local Health Unit (Unidade Local de Saúde do Nordeste, ULSNE), Hospital Unit of Bragança. This service integrates the second level of care and, due to its characteristics and geographical location, is required to transfer a large number of patients. The target population of this study consisted of all patients who, under the responsibility of SUMC, were transferred between hospitals in an ambulance with supervision of the service's team during the study period. Patients who were transferred in an air ambulance and those who were supervised by external teams were excluded from the study. The final sample was composed of 184 patients (Figure 2).

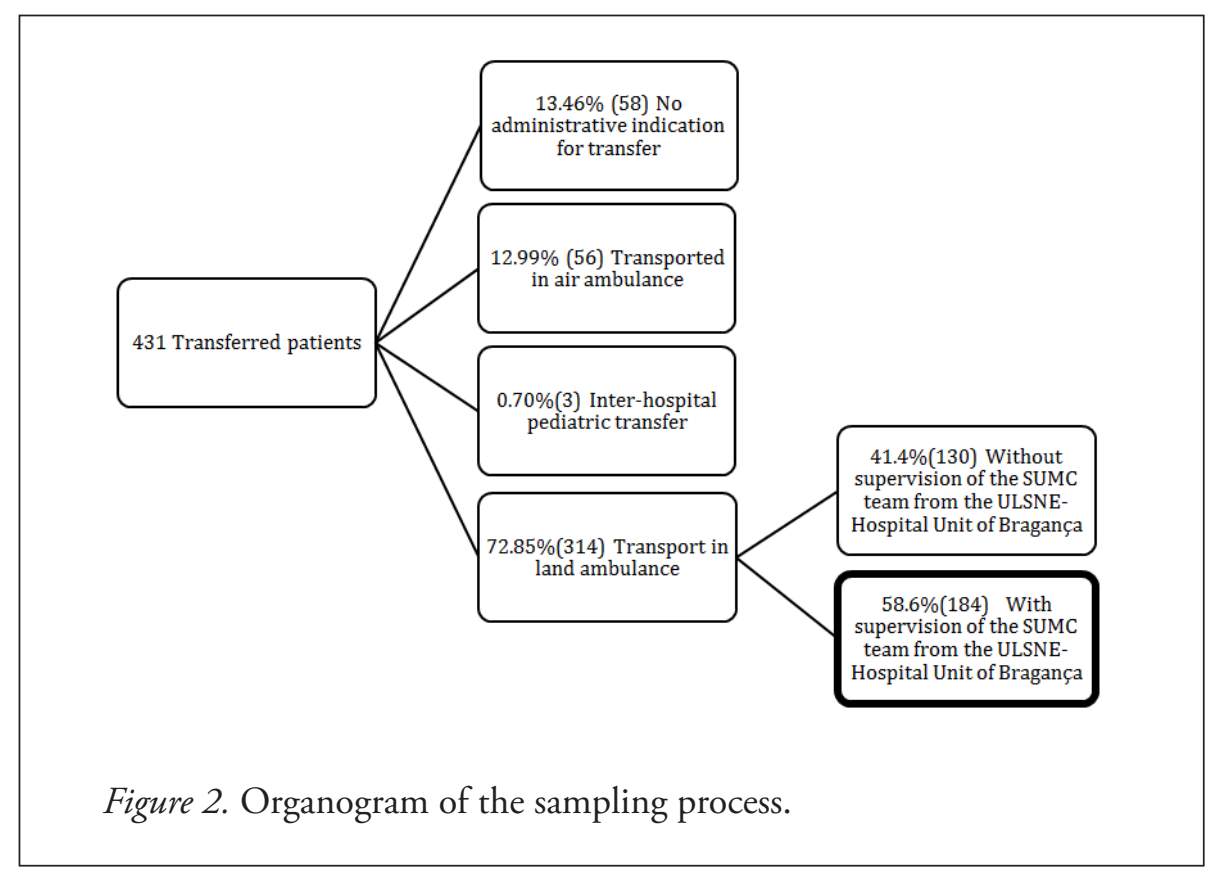

Data were collected in March 2017 from patients who were transferred from the SUMC of ULSNE - Hospital Unit of Bragança in a land ambulance. This information was provided to the researcher, anony- mously, by the head of the service.

Data were collected using the inter-hospital transport form which was used at the SUMC of ULSNE - Hospital Unit of Bragança. This form has information on the patient (age, 
gender, and place of origin), the necessary transport (hospital of origin and destination), the reason for transfer, the transport team, the patient's hemodynamic and neurological status, clinical diagnosis, procedures already performed, and the patient's history and examinations. Based on these parameters, each patient is assigned with a risk score that is calculated using the patient transport risk stratification scale to determine the type of supervision. This scale ranges from 0 to 20 points, where 0-2 does not require qualified supervision, 3-6 supervision of a nurse, and $\geq 7$ or $<7$ and item scoring 2 requires supervision of a physician and a nurse. The nurse who supervises the patient during inter-hospital transport is responsible for these records. Collected data were entered and analyzed using IBM SPSS Statistics Version 21.0. Data were encoded to ensure participants' anonymity and confidentiality. For the ordinal variables, absolute and relative frequencies were calculated, and the chi-square test - or Fisher's exact test, in alternative - was used to compare proportions. The significance level was set at 5\%. The study obtained a favorable opinion of the Ethics Committee and was authorized by the Chairman of the Board of Directors of UL-
SNE. The fundamental rights established in the Nuremberg Code and the Declaration of Helsinki were met.

\section{Results}

The study sample was composed of 184 patients: $58.7 \%$ were men and the most prevalent age range was 71-80 years (33.2\%). Most patients lived in the district of Bragança (97.8\%) and the municipality of Bragança (46.2\%); 63.6\% lived in a rural area and $36.4 \%$ in an urban area.

With regard to the clinical diagnosis, 31.5\% (58) of patients were diagnosed with neurological disease, $27.7 \%$ (51) with cardiovascular disease, $12 \%$ (22) had no diagnosis, $8.2 \%$ (15) were diagnosed with infectious/immunological disease, and 6.5\% (12) with respiratory disease. The remaining patients $(14.1 \%$; 26$)$ had other diagnoses. A statistically significant difference was found in the distribution of proportions between the patient's clinical diagnosis and the type of supervision $(p=0.000)$. Patients with cardiovascular disease $(69.0 \%)$ were supervised by a physician and a nurse (Table 1 ).

Table 1

Distribution of participants according to the type of supervision and clinical diagnosis

\begin{tabular}{|c|c|c|c|c|}
\hline \multirow[b]{3}{*}{ Clinical Diagnosis } & \multicolumn{3}{|c|}{ Type of Supervision } & \\
\hline & Nurse & $\begin{array}{c}\text { Nurse + } \\
\text { Physician }\end{array}$ & Total & \\
\hline & $\begin{array}{l}\text { N(\%line) } \\
\text { \%column }\end{array}$ & $\begin{array}{l}\mathrm{N}(\% \text { line }) \\
\% \text { column }\end{array}$ & $\begin{array}{l}\mathrm{N}(\% \text { line }) \\
\% \text { column }\end{array}$ & $\begin{array}{l}X^{2} \\
p\end{array}$ \\
\hline Cardiovascular disease & $\begin{array}{c}22(43.1 \%) \\
15.5 \%\end{array}$ & $\begin{array}{c}29(56.9 \%) \\
69.0 \%\end{array}$ & $\begin{array}{c}51(100 \%) \\
27.7 \%\end{array}$ & \\
\hline Neurological disease & $\begin{array}{c}56(96.65 \%) \\
39.4 \%\end{array}$ & $\begin{array}{c}2(3.4 \%) \\
4.8 \%\end{array}$ & $\begin{array}{c}58(100 \%) \\
31.5 \%\end{array}$ & \\
\hline Infectious/immunological disease & $\begin{array}{c}13(86.7 \%) \\
9.2 \%\end{array}$ & $\begin{array}{c}2(13.3 \%) \\
4.8 \%\end{array}$ & $\begin{array}{c}15(100 \%) \\
8.2 \%\end{array}$ & 49.476 \\
\hline Respiratory disease & $\begin{array}{c}10(83.3 \%) \\
7.0 \%\end{array}$ & $\begin{array}{c}2(9.1 \%) \\
4.8 \%\end{array}$ & $\begin{array}{c}12(100 \%) \\
6.5 \%\end{array}$ & 0.000 \\
\hline No diagnosis & $\begin{array}{c}20(90.9 \%) \\
14.1 \%\end{array}$ & $\begin{array}{c}5(19.2 \%) \\
11.9 \%\end{array}$ & $\begin{array}{c}22(100 \%) \\
12.0 \%\end{array}$ & \\
\hline Other diagnoses & $\begin{array}{c}21(80.8 \%) \\
14.8 \% \\
\end{array}$ & $\begin{array}{c}5(19.2 \%) \\
11.9 \%\end{array}$ & $\begin{array}{c}26(100 \%) \\
14.1 \%\end{array}$ & \\
\hline Total & $\begin{array}{c}142(77.2 \%) \\
100 \%\end{array}$ & $\begin{array}{c}42(22.8 \%) \\
100 \%\end{array}$ & $\begin{array}{c}184(100 \%) \\
100 \%\end{array}$ & \\
\hline
\end{tabular}


Transferred patients' most frequent comorbidities were cardiovascular diseases, $67.9 \%$ (125), followed by endocrine/metabolic diseases, $54.9 \%$ (101). Immunological/infectious diseases were the least frequent diseases, $8.2 \%$ (15). The majority of patients,
$69 \%$ (127), were transferred by the internal medicine unit and $28.8 \%$ (53) by the general surgery unit. The Fisher's exact test found a statistically significant difference $(p=0.027)$ in the distribution of the type of supervision according to the care unit of origin (Table 2).

Table 2

Distribution of participants according to the type of supervision and care unit of origin

\begin{tabular}{|c|c|c|c|c|}
\hline \multirow[b]{3}{*}{ Care unit of origin } & \multicolumn{3}{|c|}{ Type of Supervision } & \\
\hline & Nurse & $\begin{array}{c}\text { Nurse + } \\
\text { Physician }\end{array}$ & Total & \\
\hline & $\begin{array}{l}\text { N(\%line) } \\
\text { \%column }\end{array}$ & $\begin{array}{l}\mathrm{N}(\% \text { line }) \\
\text { \%column }\end{array}$ & $\begin{array}{l}\text { N(\%line) } \\
\text { \%column }\end{array}$ & $\begin{array}{c}\text { Fischer's test } \\
p\end{array}$ \\
\hline General surgery & $\begin{array}{c}47(88.7 \%) \\
33.1 \%\end{array}$ & $\begin{array}{c}6(11.3 \%) \\
14.3 \%\end{array}$ & $\begin{array}{c}53(100 \%) \\
28.8 \%\end{array}$ & \\
\hline Internal medicine & $\begin{array}{c}91(71.7 \%) \\
64.1 \%\end{array}$ & $\begin{array}{c}36(28.3 \%) \\
85.7 \%\end{array}$ & $\begin{array}{c}127(100 \%) \\
69.0 \%\end{array}$ & $\begin{array}{c}6.929 \\
p=0.027\end{array}$ \\
\hline Others & $\begin{array}{c}4(100 \%) \\
2.8 \%\end{array}$ & $\begin{array}{c}0(0.0 \%) \\
0.0 \%\end{array}$ & $\begin{array}{c}4(100 \%) \\
2.2 \%\end{array}$ & \\
\hline Total & $\begin{array}{c}142(77.2 \%) \\
100 \%\end{array}$ & $\begin{array}{c}42(22.8 \%) \\
100 \%\end{array}$ & $\begin{array}{c}184(100 \%) \\
100 \%\end{array}$ & \\
\hline
\end{tabular}

The most common reasons for transfer were specialist consultation, $38 \%(70)$, and therapeutic intervention, $37 \%$ (68). In addi- tion, the supervision of a physician and a nurse was more frequent $(42.9 \%)$ in these cases (Table 3).

Table 3

Distribution of participants according to the type of supervision and reason for transfer

\begin{tabular}{|c|c|c|c|c|}
\hline \multirow[b]{3}{*}{ Reason for transfer } & \multicolumn{3}{|c|}{ Type of Supervision } & \\
\hline & Nurse & $\begin{array}{c}\text { Nurse + } \\
\text { Physician }\end{array}$ & Total & \\
\hline & $\begin{array}{l}\text { N(\%line) } \\
\text { \%column }\end{array}$ & $\begin{array}{l}\mathrm{N}(\% \text { line }) \\
\text { \%column }\end{array}$ & $\begin{array}{l}\mathrm{N}(\% \text { line }) \\
\text { \%column }\end{array}$ & $\begin{array}{c}X^{2} \\
p\end{array}$ \\
\hline Specialist consultation & $\begin{array}{c}52(74.3 \%) \\
36.6 \%\end{array}$ & $\begin{array}{c}18(25.7 \%) \\
42.9 \%\end{array}$ & $\begin{array}{c}70(100 \%) \\
38.0 \%\end{array}$ & \\
\hline Diagnostic exams & $\begin{array}{c}17(89.5 \%) \\
12.0 \%\end{array}$ & $\begin{array}{c}2(10.5 \%) \\
\quad 4.8 \%\end{array}$ & $\begin{array}{c}19(100 \%) \\
10.3 \%\end{array}$ & 3.460 \\
\hline Interventions & $\begin{array}{c}50(73.5 \%) \\
35.2 \%\end{array}$ & $\begin{array}{c}18(26.5 \%) \\
42.9 \%\end{array}$ & $\begin{array}{c}68(100 \%) \\
37.0 \%\end{array}$ & 0.334 \\
\hline Outros & $\begin{array}{c}23(85.2 \%) \\
16.2 \%\end{array}$ & $\begin{array}{c}4(14.8 \%) \\
9.5 \%\end{array}$ & $\begin{array}{c}27(100 \%) \\
14.7 \%\end{array}$ & \\
\hline Total & $\begin{array}{c}142(77.2 \%) \\
100 \%\end{array}$ & $\begin{array}{c}42(22.8 \%) \\
100 \%\end{array}$ & $\begin{array}{c}184(100 \%) \\
100 \%\end{array}$ & \\
\hline
\end{tabular}


In relation to the risk score, $15.8 \%$ (29) of patients who had a risk score $0-2$, but no indication for qualified supervision, were supervised by a nurse. Of the patients with a score 3-6 points, $45.7 \%$ (84), 98.8\% were supervised by a nurse and $1.2 \%$ were supervised by a physician and a nurse. Of the patients with a risk score $\geq 7$ or $<7$ and item scoring 2 (38.6\%), $42.3 \%$ were supervised by a nurse and $57.7 \%$ were supervised by a physician and a nurse. The chi-square test found a statistically significant difference $(p=0.000)$ in the distribution of proportions between the type of supervision and the risk score. Most patients with higher risk scores were supervised by a physician and a nurse $(57.7 \%)$, and $42.3 \%$ of the patients with indication for supervision of a physician and a nurse based on the risk score were only supervised by a nurse (Table 4).

Table 4

Distribution of participants according to the type of supervision and risk score

\begin{tabular}{|c|c|c|c|c|}
\hline \multirow[b]{3}{*}{ Risk score } & \multicolumn{3}{|c|}{ Type of Supervision } & \\
\hline & Nurse & $\begin{array}{c}\text { Nurse + } \\
\text { Physician }\end{array}$ & Total & \\
\hline & $\begin{array}{l}\text { N(\%line }) \\
\text { \%column }\end{array}$ & $\begin{array}{l}\mathrm{N}(\% \text { line }) \\
\text { \%column }\end{array}$ & $\begin{array}{l}\mathrm{N}(\% \text { line }) \\
\text { \%column }\end{array}$ & $p$ \\
\hline $0-2$ & $\begin{array}{l}29(100 \%) \\
20.4 \%\end{array}$ & $\begin{array}{c}0(0.0 \%) \\
0.0 \%\end{array}$ & $\begin{array}{c}29(100 \%) \\
15.8 \%\end{array}$ & \\
\hline $3-6$ & $\begin{array}{c}83(98.8 \%) \\
20.4 \%\end{array}$ & $\begin{array}{c}1(1.2 \%) \\
2.4 \%\end{array}$ & $\begin{array}{c}84(100 \%) \\
45.7 \%\end{array}$ & $\begin{array}{l}0.048 \\
0.000\end{array}$ \\
\hline $\begin{array}{l}\geq 7 \text { or }<7 \text { and item scor- } \\
\text { ing } 2\end{array}$ & $\begin{array}{c}30(42.3 \%) \\
21.1 \%\end{array}$ & $\begin{array}{l}41(57.7 \%) \\
97.6 \%\end{array}$ & $\begin{array}{c}71(100 \%) \\
38.6 \%\end{array}$ & \\
\hline Total & $\begin{array}{c}142(77.2 \%) \\
100 \%\end{array}$ & $\begin{array}{c}42(22.8 \%) \\
100 \%\end{array}$ & $\begin{array}{c}184(100 \%) \\
100 \%\end{array}$ & \\
\hline
\end{tabular}

\section{Discussion}

This research work had some difficulties and limitations due to the small number of scientific articles published on this topic, which is why the discussion will focus on the interpretation of the collected data. There may have been some situations of underreporting, where the service team supervised patients during inter-hospital transport but did not complete the data collection tool.

\section{Sociodemographic characterization}

In this sample, $97.8 \%$ of patients lived in the district of Bragança, and $46.2 \%$ lived in the municipality of Bragança. Regarding the age group, $33.2 \%$ were aged $71-80$ years, which may be associated with the population ageing in the region (200 older people per 100 young people in 2015; PORDATA, Base de Dados Portugal Contemporâneo, 2015). The majority of patients lived in the district and municipality of Bragança because this is the area of reference of the SUMC of ULSNE - Hospital Unit of Bragança. No study with a sociodemographic characterization of the target population was found, thus preventing any possible comparison.

\section{Characterization of the clinical profile}

Cardiovascular diseases (67.9\%) and endocrine diseases $(54.9 \%)$ were the most prevalent comorbidities, followed by respiratory, renal, immunological/infectious diseases, mental/behavioral, and hematological diseases. The most common diagnosis was neurological disease, followed by cardiovascular disease. In an observational study conducted by Wiegersma et al. (2011) in the northeast region of the Netherlands on patient transfers to more differentiated hospitals, the main diagnosis of transfer was respiratory failure (27\%), followed by sep- 
sis $(17.6 \%)$, and multi-organ failure (10.8\%). These results are contrary to those found in this study, where respiratory diseases appear in fifth place. Septic shock was the most common diagnosis reported by Sethi and Subramanian (2014). This difference in results may be associated with the response capacity of the Intensive Care Unit of the Hospital Unit of Bragança to treat patients with immunological/infectious and respiratory diseases, not needing to transfer them. On the other hand, there is a need to transfer neurological and cardiac patients because the hospital does not have response capacity to treat these patients. The internal medicine unit was responsible for $69 \%$ of transfers, followed by the general surgery unit $(28.8 \%)$, which can be associated with the population ageing in the region (200 elderly people per 100 young people in 2015; Base de Dados Portugal Contemporâneo, 2015) and, consequently, with an increased number of associated medical conditions (Direção-Geral da Saúde, 2014). In a literature review, Droogh et al. (2015) concluded that the number of transfers is likely to increase with the centralization of specialized care. Wiegersma et al. (2011) found that specialist consultations or advanced/specialized therapy were the main indications for transfer, which is in line with the results found in this study, where $38 \%$ of patients were transferred to be examined by specialist and $37 \%$ to perform specialized therapeutic interventions. The SUMC of ULSNE - Hospital Unit of Bragança integrates the second level of care and is located in the north region of the country; hence, patients who cannot be treated there must be transferred. The Hospital of Vila Real receives the majority of patients with cardiovascular diseases and was responsible for $34.2 \%$ of the transferred patients; the stroke unit of the Hospital of Macedo de Cavaleiros usually treats patients with neurological/medical diseases and received $23.9 \%$ of the transferred patients; and, finally, the General Hospital of Santo António treats patients with neurological/surgical diseases and received $20.1 \%$ of the transferred patients.

\section{Characterization of the type of supervision during transport}

Etxebarria et al. (1998) concluded that the application of risk scores allowed allocating (technical and human) resources effectively for a safe inter-hospital transport of critically ill patients. In their study (a total sample of 172 patients), 59.3\% (102) of patients had a risk score $<7$ and were transferred under the supervision of a nurse and $40.7 \%(70)$ of patients had a risk score 7 and were transferred under the supervision of a physician and a nurse. In this study, $15.8 \%$ of patients had a risk score $0-2,45.7 \%$ had a score of 3-6, $18.5 \%$ had a score $>7$, and $20.1 \%$ had a score $<7$ and item scoring 2 . Of the total sample, $77.2 \%$ of the patients were transferred under the supervision of a nurse and $22.8 \%$ under the supervision of a physician and a nurse. In actual practice, all cases that did not require qualified supervision during transport were supervised by a nurse. In the transfers that required the supervision of a nurse based on the risk score, $98.8 \%$ of the patients were supervised by a nurse and $1.2 \%$ of them were supervised by a physician and a nurse. Based on the risk score, $38.6 \%$ of patients required the supervision of a physician and a nurse. This type of supervision was found in $57.7 \%$ of cases, while the supervision was performed only by a nurse in the remaining $42.3 \%$ of the cases. The analysis of the chi-square test found a statistically significant difference $(p$ $=0.000)$ in the distribution of proportions between the type of supervision and the risk score. Most patients with higher risk scores were supervised by a physician and a nurse $(57.7 \%)$. Of the total number of patients with indication of transfer with supervision of a physician and a nurse based on the risk score, $42.3 \%$ of patients were only supervised by a nurse. The allocation of human resources to patient supervision is statistically associated with the risk score. Most patients with higher risk scores were supervised by a physician and a nurse; however, some patients who required supervision of a physician and a nurse were transferred only under the supervision of a nurse. This fact may be associated with the lack of physicians in the hospitals of the area under analysis (north interior region of the country), where there is a ratio of 213.7 inhabitants/physician, when compared to 47.8 inhabitants/physician in the northern coast region of the country (PORDATA, Base de Dados Portugal Contemporâneo, 2015). 
Some patients who did not require qualified supervision based on the risk score were also transferred with the supervision of a nurse. In these cases, the physician responsible for the transfer may have decided to maintain the level of supervision of the unit of origin during transport.

Sethi and Subramanian (2014) have concluded that patients with a risk score $\geq 7$ are at high risk for critical events and subsequent mortality. In this case, continuity of care should be maintained during the inter-hospital transport, and the team must be trained and qualified to anticipate, manage, and resolve any technical and medical difficulties that may arise during transport. Kulshrestha and Singh (2016) reinforce this conclusion while also emphasizing that the decision to transport a patient based on the benefit-risk assessment and its planning based on team communication and risk score are essential to determine the clinical safety of the transport, both for the patient and the transport team. Droogh et al. (2015) argue that, despite the use of scores, the transport itself can also influence the severity score to the extent that inter-hospital transport is associated with the risk of physiological deterioration and adverse events. This risk is proportional to the patient's level of severity before transport and team's lack of experience and knowledge. The authors also mention that a specialized team, that is adjusted to the transport risk score, will be better able to stabilize the patient before transfer and anticipate or respond to complications.

The comparison of the supervision found in this study sample to the findings of the above-mentioned studies showed gaps when choosing the transport team, particularly in patients with a risk score $\geq 7$ or $<7$ and item scoring 2, who were transferred under the supervision of a nurse, thus exposing the patient and the team more to potential complications. In these cases, the patient should be transferred under the supervision of a physician and a nurse in order to ensure the quality of care and surveillance. According to Nunes (2009), the transport must be carried out with the lowest possible risk and the highest possible safety to ensure the patient's right to quality care, of which safety is a critical com- ponent. The author also emphasizes that, in their decision-making process and for the patient's benefit, nurses may analyze the factors involved and, for the patient's benefit, refuse to accompany the patient until the minimum and desirable conditions are in place to transport the patient safely and with the least possible risk, both for the patient and the team. However, our study revealed that patients were transferred under the supervision of a nurse, without implementing the the desirable safety conditions.

\section{Conclusion}

The results of this study allowed concluding that the risk score influences the type of supervision during inter-hospital transport. Most patients with higher risk scores were supervised by a physician and a nurse; patients with a risk score 3-6 were supervised by a nurse; and patients with a risk score $0-2$ were supervised by a nurse, even though they did not require qualified supervision. These situations revealed an excessive use of nursing resources. The type of patient supervision is associated with the clinical diagnosis and the care unit of origin. Patients diagnosed with cardiovascular diseases and patients transferred from the internal medicine unit were most often supervised by a physician and a nurse during transport.

An association was found between the care unit of origin and the type of supervision. The supervision of a physician and a nurse prevailed in transfers from the internal medicine unit, which is in line with these patients' transport risk score. This study aimed to contribute towards the advancement of knowledge in the area of inter-hospital transport of critically ill patients. These results are expected to help improving the process of patient transfer by facilitating the management of human resources with the purpose of maximizing health gains. Future studies should be conducted to include variables related to the occurrence of complications during transport. An inter-hospital transport protocol should be developed to identify the human and material resources necessary for a safe transport and to avoid the excessive use of resources. 


\section{References}

Comissão de Reavaliação da Rede Nacional de Emergência/Urgência. (2012). Reavaliação da Rede Nacional de Emergência e Urgência. Retrieved from http:// www.portaldasaude.pt/NR/rdonlyres/0323CC90-45A4-40E4-AA7A-7ACBC8BF6C75/0/ReavaliacaoRedeNacionalEmergenciaUrgancia.pdf.

Despacho no 10319/14 de 11 de agosto. (2014). Diário da República no 153/14, II Série. Assembleia da República. Lisboa, Portugal.

Direção-Geral da Saúde. (2014). Portugal: Idade maior em números. Retrieved from https://www.dgs.pt/ estatisticas-de-saude/estatisticas-de-saude/publicacoes/portugal-idade-maior-em-numeros-2014pdf.aspx.

Droogh, J., Smit, M., Absalom, A., Ligtenberg, J., \& Zijlstra, J. (2015). Transferring the critically ill patient: Are we there yet?. Crit Care, 19(1), 62-68. doi: 10.1186/s13054-015-0749-4.

Etxebarría, M. J., Serrano, S., Ruiz Ribó, R., Cía, M., Olaz, F., \& López, J. (1998). Prospective application of risk scores in the interhospital transport of patients. Eur J Emerg Med, Mar, 5(1),13-7.

Instituto Nacional de Emergência Médica. (2012). Transporte do doente crítico. Lisboa, Portugal.

Kulshrestha, A., \& Singh, J. (2016). Inter-hospital and intra-hospital patient transfer: Recent concepts. Indian Journal of Anaesthesia, 60(7), 451-457. doi: 10.4103/0019-5049.186012.
Lacerda, M., Cruvinel, M., \& Silva, W. (2011). Transporte de pacientes: Intra-hospitalar e inter-hospitalar. Retrieved from http://www.pilotopolicial.com. $\mathrm{br} /$ transporte-de-pacientes-intra-hospitalar-e-inter-hospitalar/.

Nunes, F. (2009). Tomada de decisão do enfermeiro no transporte do doente crítico. Revista Nursing, 246. Retrieved from http://www.forumenfermagem.org/ dossier-tecnico/revistas/nursing/item/3526-tomada-de-decisao-do-enfermeiro-no-transporte-dodoente-critico\#.WNrGmRLytsM.

PORDATA - Base de Dados Portugal Contemporâneo. (2015). Retrieved from http://www.pordata.pt/.

Rua, F. (1999). Oxigenação durante o transporte do doente ventilado. Revista Portuguesa de Medicina Intensiva, 1.

Sethi, D., \& Subramanian, S. (2014). When place and time matter: How to conduct safe inter-hospital transfer of patients. Saudi Journal of Anaesthesia, 8(1),104-13. doi: 10.4103/1658-354X.125964.

Ordem dos Médicos (Comissão da Competência em Emergência Médica) e Sociedade Portuguesa de Cuidados Intensivos. (2008). Transporte de doentes criticos. Retrieved from http://www.spci.pt/Docs/ GuiaTransporte/9764_miolo.pdf.

Wiegersma,J., Joep, D., Absalon, A., Zijlstra, J., Fokkema,J., \& Ligtenberg, J. (2011). Quality of interhospital transport of the critically ill: Impact of a Mobile Intensive Care Unit with a specialized retrieval team. Crit Care, 15(1), 75-82. doi: 10.1186/cc10064. 
